The University of San Francisco

USF Scholarship: a digital repository @ Gleeson Library |

Geschke Center

Philosophy

College of Arts and Sciences

2010

\title{
Temporal Indiscriminateness: The Case of Cluster Bombs
}

Thomas A. Cavanaugh

University of San Francisco, cavanaught@usfca.edu

Follow this and additional works at: http://repository.usfca.edu/phil

Part of the Philosophy Commons

\section{Recommended Citation}

Cavanaugh, Thomas A., "Temporal Indiscriminateness: The Case of Cluster Bombs" (2010). Philosophy. Paper 22.

http://repository.usfca.edu/phil/22

This Article is brought to you for free and open access by the College of Arts and Sciences at USF Scholarship: a digital repository @ Gleeson Library | Geschke Center. It has been accepted for inclusion in Philosophy by an authorized administrator of USF Scholarship: a digital repository @ Gleeson

Library | Geschke Center. For more information, please contact repository@usfca.edu. 


\section{Temporal Indiscriminateness: The Case of Cluster Bombs}

T.A. Cavanaugh, Ph.D., Professor of Philosophy, USF

Penultimate version of article prior to publication,

Final version found in: Science and Engineering Ethics, (2010) 16:135-145

Thinkers speak of weapons as "intrinsically" immoral, referring to weapons that are “inherently cruel", "inherently indiscriminate", or "inherently unchivalrous" [1, p.694]. In the history of reflection upon war certain weapons have at times been deemed out of bounds. They have been so judged - if not as just or unjust, ethical or unethical - in terms indicating that their use falls short of some relevant standard of behavior, be it that of the ancient warrior which rejected arrows for obviating hand-to-hand combat or, more recently (1995), Protocol IV of the United Nations' Convention on Conventional Weapons which outlaws blinding lasers as gratuitously harmful [2]. Over the past six decades, a robust debate concerning the morality of nuclear weapons has occupied just war theorists [3]. With the end of the cold war, that conversation has subsided while debates concerning research, development, and use of weapons continues $[1,4]$.

The recent (2008) Convention on Cluster Munitions (CCM) bans the use, development, production, acquisition, retention, or transfer of standard cluster munitions (while permitting certain smart cluster munitions)[5]. Anti-personnel cluster bombs dispense numerous submunitions over a wide area. The various designs of cluster submunitions call for them to detonate above ground, upon impact, or on the ground after a specified delay. Cluster bombs 
have proven particularly effective against ground forces as submunitions saturate a large area with numerous lethal explosions. The central moral problem surrounding cluster bombs concerns their submunitions' high failure rate which results in unexploded ordnance which, in turn, leads to increased casualties to non-combatants (and others, including friendlies, or one's own soldiers and allies).

As noted in the CCM, the ban is based upon the well-accepted principle of discrimination that holds that,... the parties to a conflict shall at all times distinguish between the civilian population and combatants and between civilian objects and military objectives and accordingly direct their operations against military objectives only [5, p.3].

The CCM bans standard cluster munitions insofar as they are indiscriminate weapons that fail to permit those who employ them from distinguishing between combatants and civilians. A weapon may be indiscriminate, however, in a variety of ways. How, precisely, are cluster bombs indiscriminate?

This paper argues that contemporary anti-personnel cluster bombs exemplify temporal indiscriminateness. Temporal indiscriminateness - an idea that will be introduced and explained in what follows - violates non-combatant immunity. For, as will be argued, to honor non-combatant immunity - in addition to not targeting civilians - one must target combatants. Combatants, however, occupy both space and time. Thus, to target combatants one must hit both a spatial and a temporal target. Accordingly, a weapon can fail to discriminate spatially or 
temporally. Due to the high dud rates of their sub-munitions, cluster bombs fail to discriminate temporally. The temporal indiscriminateness of cluster submunitions frustrate one's ability to target combatants while resulting in avoidable harm to non-combatants (and, as will be noted, friendly combatants). By considering the specific injustice posed by cluster munitions to non-combatant immunity, this paper makes explicit our understanding of the principle of discrimination as including not only place or location, but also time. That is, this paper shows that in addition to a weapon being spatially indiscriminate, it can also be temporally indiscriminate.

Before developing the idea of temporal indiscriminateness, a brief recounting of the elements of just war are in order. For the purposes of this paper, the moral criteria bearing on the conduct of war (ius in bello, particularly the principle of discrimination) will have the greatest import.

\section{The Elements of Just War}

Cicero, the first century B.C. Roman jurist and senator, introduces the elements of just war theory [6]. In his consideration of our obligations to those who have offended us, he discusses duties having to do with war. According to Cicero, one legitimately resorts to war when discussion, the appropriately human method of contending, affords no viable resolution. In his account, one justly has recourse to war when one fails to receive demanded satisfaction for injury, declares war, and seeks a peace free from further injury. One conducts war legitimately when legally authorized soldiers offer humane treatment to the vanquished and quarter to those who surrender. In what amounts to a few brief paragraphs, Cicero limns what develops into just war theory, particularly in the thought of Augustine and Aquinas. That account retains, makes 
explicit, and elaborates upon Cicero's implicit distinction between those criteria of justice concerning the licitness of waging war at all (ius ad bellum) and those criteria concerning how one justly conducts war (ius in bello).

The ius ad bellum conditions require: the just cause of self- or other-defense; the intent of that just cause and not ulterior motives; the exhaustion of alternate means of redress short of war; declaration by the legitimate authority; the good of peace to be achieved outweighing the inevitable evils of war; and, finally, decent prospects for success.

In a war legitimate according to the above conditions, the ius in bello criteria amount to two mandates, applying to conduct. First, the principle of discrimination or non-combatant immunity (which bears most directly on this paper's topic) demands that one wage war against belligerents exclusively. Second, the principle of proportionality commands that the harm attendant upon any military action shall be reduced to its practical minimum and proportioned to the importance of its proximate military goal in the latter's relation to the ultimate goals of victory and peace. These two criteria constrain the violence of war. Moreover, as has been duly noted by Fichtelberg and Forge separately $[1,4]$ they do so for soldiers and their leaders as well as for engineers in research and development bearing on weapons. In our consideration of contemporary cluster bombs we shall see that it is their failure to function properly which renders them in violation of non-combatant immunity and, thereby, renders them unfit for use in a justly conducted war. The onus of remedying this failure to function properly falls partially upon the shoulders of those who research and develop such weapons.

Consider the principle of proportionality (briefly, as it has less import for this article). Proportionality limits the violence of war in terms of its necessity and magnitude. The killing, 
maiming, and general destructiveness of military acts ought to be no more than pragmatically necessary. Moreover, that least practically necessary harm ought to be in balance with the importance of the proximate military goal. Necessity and magnitude check one another. For great necessary violence may be out of balance with the significance of an otherwise modest military objective while violence in balance with an important goal may not be necessary.

\section{The Principle of Discrimination}

Turn now to the primary concern of this paper. The principle of discrimination restricts violence in respect of its target by requiring that one wield violence against combatants exclusively. In distinguishing combatants from non-combatants, discrimination depends upon differences between, for example, killing an enemy soldier in combat from killing him in hospital as he recuperates from wounds. In short, combatants in their roles as combatants may be targeted. While simple to state, this criterion can be difficult to apply. Difficulties of discerning combatant and non-combatant status, however, do not bear on the argument of this paper. For none dispute the non-combatant status of civilians harmed by unexploded ordinance due to cluster bombs.

For this paper's purposes, understanding the principle of discrimination requires a discussion of what it means to target. While this might initially appear an entirely semantic point, it addresses the important question of whether all harms of war befalling non-combatants violate the principle of discrimination. That is, once one determines who has non-combatant status, one must consider what acts violate this status. From what do non-combatants enjoy immunity?

To answer this question, one initially notes the difference between targeting and hitting. In other words - attending to the earlier-noted semantic point - what is it to target? To target one 
must seek and try to hit; to hit one need not target. Non-combatants whom one hits while not aiming at them have not been targeted. In that narrow respect, one has not violated their immunity. Of course, this only serves as an initial response to the question. For while targeting non-combatants most egregiously contravenes the principle of discrimination, the principle calls for more than simply not targeting civilians. It also requires that one actually target combatants. This requirement might puzzle at first. Upon reflection, however, one sees that it completes the principle of discrimination.

Consider precisely what the principle of discrimination calls for. As noted in the Convention on Cluster Munitions, combatants are to "direct their operations against military objectives only" (emphases added) [5, p.3]. This is a standard presentation of the principle of discrimination. If one directs the force of war against military objectives only, one will, of course, not target non-combatants. Simply not targeting non-combatants, however, does not suffice to satisfy the principle. For the principle also requires that one direct operations against combatants. One must target combatants. Thus, harms that befall non-combatants from one's failure adequately to target combatants violate the principle of discrimination. For the principle mandates both that 1) non-combatants will not be targeted and that 2) combatants will be targeted.

What extra benefit do non-combatants derive from the requirement to target combatants? This requirement enhances non-combatant immunity by mandating that they not be subject to harms from undirected force. Consider, for example, unguided rockets and missiles (such as the Qassam used by Hamas) which cannot be targeted. Willy nilly, they will hit someone or something in a large, indefinite area. Where, what, and whom they will hit, however, cannot be 
determined. Such weapons cannot be targeted spatially. This is perhaps the most basic feature necessary for a weapon to enable those who use it to discriminate. For a weapon that will haphazardly hit someone or thing somewhere in an indefinite area occupied by combatants, non-combatants, military targets, and non-military buildings cannot be used by one who aspires to abide by the principle of discrimination.

Again, note that this is not because such weapons are aimed at non-combatants; rather, it is because they are not aimed at all. One here sees that to honor non-combatant immunity it does not suffice not to aim at non-combatants; one must actually aim (at combatants, of course). Accordingly, weapons that cannot be targeted spatially entirely fail to enable those who use them to discriminate. One responds to this indiscriminateness by not employing such weapons at all.

This is not to argue that weapons must be so accurate and precise as to eliminate non-combatant casualties. Rather, it is to hold that the ability to aim a weapon serves as the bare minimum requirement a weapon must meet to enable discrimination. An unguided missile, by definition and by (lack of) design, fails in this crucial respect. Failing modifications of such weapons, one may not employ them without violating the principle of discrimination insofar as it mandates the actual targeting of combatants.

While the inability to aim a weapon renders it indiscriminate, simply being able to aim a weapon does not thereby make it discriminate. For, as precision guided munitions indicate, spatial targetability admits of degrees. Thus, so does the degree of discriminateness and indiscriminateness attributable to a weapon. The more accurately and precisely a weapon can be targeted (at combatants, of course), the more it abides by the principle of discrimination. Conversely, the less accurately and precisely a weapon can be targeted, the more it threatens to 
violate the principle of discrimination. Of course, degrees of accuracy and precision are not fixed; rather, they change as technology advances. Thus, one makes judgements concerning discriminateness and indiscriminateness relative to the current practicable capabilities for accuracy and precision.

\section{Cluster Bombs and Temporal Indiscriminateness}

Cluster bombs can be adequately targeted spatially and, thereby, do not fail the most basic test of discrimination, spatial targetability. (One notes that their dispersal over areas as large as the size of three football fields unsuits them for use when non-combatant immunity calls for greater precision.) They do, however, suffer from another kind of indiscriminateness, namely, temporal indiscriminateness. That is, while designed to explode shortly after deployment, their high failure rate leads to numerous submunitions becoming, in effect, land mines that explode at a later time, often upon subsequent contact with whomever happens upon them, be it enemy soldiers, one's own troops, or civilians.

It is difficult to find reliable data on the failure rates under actual combat conditions of the various submunitions currently stockpiled and employed in conflicts. Under ideal non-combat test-conditions it appears that the lowest failure rate is $5 \%$. This would result, on average for each cluster bomb deployed, in over 22 unexploded potentially lethal sub-munitions spread over an area of 1-3 football fields [7, p. 29]. (The number of unexploded submunitions varies from one bomb to another as bombs contain from 200 to 700 - and sometimes more submunitions.) Of course, combat conditions are less than ideal and one would expect higher failure rates, as, indeed, appears to be the case [7, p. 27-29]. A brief consideration of civilian and friendly-combatant casualties attributable to these unexploded submunitions illustrates the 
problem of temporal indiscriminateness.

After NATO's use in Kosovo of BL 755 and CBU-87B cluster bombs in April through early June of 1999, the International Committee of the Red Cross (ICRC) recorded civilian casualties from 1 June 1999 to 31 May of 2000. Unexploded cluster munitions accounted for 102 non-combatant casualties (deaths or injuries), representing slightly more than 36-percent of such casualties. The civilian casualties attributable to unexploded cluster submunitions equaled that due to anti-personnel mines. Moreover, the victims of unexploded cluster munitions were almost 5 times more likely to be under 14 years of age than those injured by anti-personnel mines [8, p.9]. For the same time period, the United Nations Mission in Kosovo (UNMIK) Mine Action Coordination Center (MACC) collected a larger pool of data. The UNMACC data cited by the ICRC indicates that unexploded cluster bomblets accounted for 51-percent of civilian deaths (50) and 30-percent of overall casualties (151) while unexploded anti-personnel mines accounted for 22-percent of civilian deaths (22) and 36-percent of overall casualties (176). Compared to anti-personnel mines, unexploded cluster submunitions proved more lethal and more likely to inflict casualties on younger civilians [8, p.10].

In their use of cluster bombs, the U.S. Army and Marine Corps often employ the Multiple Launch Rocket System (MLRS). As the U.S. Government Accounting Office (GAO) reported in the Fall of 2002,

[w]ith a 95-percent submunition reliability rate, a typical

fire mission of 36 MLRS rockets could produce an average of 1,368 unexploded submunitions [9, p.58].

In the same report, the GAO notes that 6-percent of U.S. casualties (80) in the First Gulf War 
could be attributed to unexploded ordnance from U.S. cluster munitions, roughly equivalent to the U.S. casualties from Iraqi land mines (the latter, of course, being purposely laid to harm U.S. forces). The U.S. Army suffered all 80 of the casualties due to unexploded cluster munitions, 22 deaths and 58 injuries $[9$, p.16]. These data appear to indicate that cluster bombs can be categorized as temporally indiscriminate weapons.

As noted earlier, however, the accuracy and precision of a weapon must be judged, not in absolute terms; rather, one must assess it in terms relative to current capabilities for accuracy and precision. In light of current capabilities, can cluster submunitions be judged temporally indiscriminate? It would appear so. For the U.S. Government Accounting Office notes that, based on actual costs to clean up unexploded ordnance due to cluster bombs on the Kuwaiti Gulf War battlefield, the U.S. Army,

estimated that the cost to reduce the dud rate by adding self-destruct fuzes for the submunitions actually used on a battlefield was comparable to the cost to clean up duds left by unimproved submunitions. The Army further recognized that, while the costs of reducing and cleaning up duds may be similar, the detrimental battlefield fratricide and countermobility effects of duds also need to be considered, as well as humanitarian concerns $[9$, p.60].

Here one sees that cluster submunitions can be made temporally more discriminate (by adding self-destruct fuzes) and that doing so compares favorably, on a strictly financial basis, with not doing so. In light of current capabilities for greater temporal discrimination, it seems reasonable 
to characterize unmodified cluster munitions as temporally indiscriminate weapons.

The idea of temporal indiscriminateness requires further elaboration. For when one speaks of the paradigmatic instance of an indiscriminate weapon, one thinks of weapons that cannot be targeted spatially. That is, one tends to identify indiscriminateness with spatial indiscriminateness. This is, of course, only natural. For to succeed at targeting or aiming is to hit a mark, an area that occupies a certain space. A weapon that cannot be guided towards any specific place is, by definition, indiscriminate (e.g., the earlier-noted Qassam rocket). To think that this is the only way for a weapon to fail in terms of the need for discrimination, however, is to err. For one's weapon also always hits a target at a certain time. This is so obvious an aspect of targeting that we do not even consider it. The failure of cluster submunitions to detonate when they are supposed to, however, brings it to our attention. Considering the high incidence of non-combatant casualties (and casualties to friendlies) linked to unexploded cluster submunitions leads some to label them as indiscriminate weapons. Others, noting that they are targetable (spatially), understandably reject this characterization. Both parties to the debate actually make valid points. For, as spatially targetable, cluster bombs are not indiscriminate; yet, as lacking sufficient temporal targetability, they are. The proposed distinction between spatial discrimination and temporal discrimination clarifies this aspect of the debate concerning cluster bombs. Current cluster bombs are temporally indiscriminate weapons.

Can one employ a temporally indiscriminate weapon while not violating non-combatant immunity? As earlier argued, spatial targetability serves as the bare minimum for a weapon to enable discrimination. A weapon that cannot be targeted spatially cannot be employed by those who hope to respect non-combatant immunity. What of a temporally indiscriminate weapon? 
Consider a (fanciful) hypothetical scenario. Say that there are temporally indiscriminate weapons analogous to spatially indiscriminate weapons such that such weapons detonate over a range of times proportionate to the range of spaces over which a spatially indiscriminate weapon (such as the Qassam rocket) detonates. It would seem that if one rejects (as one should) the spatially indiscriminate weapon for its lack of spatial targetability, by parity of reasoning, one must also reject the weapon lacking temporal targetability. For whether harm comes to non-combatants via spatial or temporal indiscriminateness has no moral relevance. The ethically significant factor is a weapon's lacking those features that enable those who use it to target combatants (who occupy specific places and times) and, thereby, follow the principle of discrimination. If a weapon lacks spatial or temporal targetability, one cannot use it while abiding by the principle of discrimination and honoring non-combatant immunity.

Of course, cluster bombs do not entirely lack temporal targetability (as, for example, the Qassam rocket does lack spatial targetability). Nonetheless, as earlier noted, simply being able to aim a weapon does not render it discriminate. For targetability admits of degrees. At what point would cluster submunitions have an acceptable degree of temporal targetability to render their use in keeping with the principle of discrimination? One finds a developed account of how to answer this question in double-effect-reasoning (DER, also referred to as the principle of double effect). In evaluating cluster bombs in terms of the just conduct of war, a consideration of DER is in order, particularly its third condition which calls for due care in eliminating or lessening foreseeable harm to non-combatants.

\section{Double-effect Reasoning and Due Diligence in Reducing Concomitant Harm}

DER consists of a set of criteria that judge the permissibility of otherwise legitimate acts 
that involve harm that, on the face of things, one ought to avoid. DER originates in the thought of the medieval philosopher-cum-theologian Thomas Aquinas. Aquinas' seminal account subsequently develops in the work of his followers, first receiving application to harms befalling non-combatants in the thought of the early sixteenth-century thinker Francisco de Vitoria. Contemporary military ethics employs double effect to evaluate, for example, bombing of an otherwise legitimate target that concomitantly harms non-combatants. DER permits an act causing benefit and harm under the following conditions:

1) the act considered independently of the harm is legitimate;

2) the agent intends the good and does not intend the harm either as an end or as a means; and, 3) considering his obligations, the consequences, and the necessity of the harm, the agent has proportionately serious reasons for acting and exercises due care to eliminate or lessen it $[10$, p.36].

Employing double effect to evaluate bombing that concomitantly harms non-combatants, one sees that certain instances of such bombing could be legitimate. For the bombing of a military target is permissible; the bomber need not intend to harm the non-combatants although he foresees that bombing the target will also harm them; and if no viable alternative exists and he diligently attempts to decrease the harm, the target could have sufficient import to outweigh the serious obligation to avoid harming non-combatants. Of course, one makes this judgment while absolutely denying the legitimacy of intentionally, deliberately, or on purpose targeting non-combatants. 
Simply aiming at combatants and not aiming at non-combatants, however, do not suffice to justify an act that does harm non-combatants. Additionally, the third condition of double-effect reasoning requires that one exercise due diligence to eliminate or lessen the foreseen harm to non-combatants; one must strive to avoid harming non-combatants.

Considering the earlier noted GAO report, the continued use of cluster munitions (that can be retro-fitted at a cost comparable to that of removing unexploded duds from the battlefield) shows a lack of due diligence in reducing or eliminating foreseen harm to non-combatants. While those who would continue to use temporally indiscriminate cluster submunitions cannot be charged thereby with targeting non-combatants, they do violate non-combatant immunity not to be subject to (temporally or spatially) indiscriminate weapons. Moreover, they discount double-effect's insistence that one exert effort to avoid harm to non-combatants. On this point, one notes that the just war theorist Michael Walzer goes so far as to argue that the measures one employs to minimize harms to non-combatants include even risking the lives of soldiers, saying, "if saving civilian lives means risking soldiers' lives, the risk must be accepted" [11, p. 156]. Certainly, if due diligence extends to soldiers accepting the risk of harm to themselves in order to prevent harm to non-combatants, it includes the technological remedies noted by the GAO. Clearly, remediable temporally indiscriminate cluster bombs violate non-combatant immunity.

Currently, there are two major proposals to reduce the harm attributable to cluster submunitions' temporal indiscriminateness. The U.S. Pentagon proposes by 2018 to use only cluster submunitions with no greater than a $1 \%$ unexploded ordnance failure rate after arming (counting a self-deactivated sub-munition as unexploded ordnance) [12, p. 2]. While, as earlier noted, precise failure rates are difficult to establish, and while failure rates in combat are 
probably higher than those under test conditions, it appears that a $1 \%$ or lower failure rate is a five-fold reduction of the current failure rate (of approximately 5\% under test conditions). While this might seem like a dramatic improvement, it partially indicates just how defective the current sub-munitions are. For, as earlier noted, the U.S. Army and Marine Corps often employ the Multiple Launch Rocket System (MLRS). Currently, the failure rate for the typical use of the MLRS (firing 36 rockets) results in 1,368 unexploded submunitions. A 1\% failure rate would result in approximately 273 unexploded submunitions, still a large number.

In contrast to the new U.S. policy, the Convention on Cluster Munitions proposes to ban all but smart cluster munitions. According to the CCM, a smart cluster munition designed "to avoid indiscriminate area effects and the risks posed by unexploded munitions" having all of the following characteristics would be permissible:

(i) Each munition contains fewer than ten explosive submunitions;

(ii) Each explosive submunition weighs more than four kilograms;

(iii) Each explosive submunition is designed to detect and engage a single target object;

(iv) Each explosive submunition is equipped with an electronic self-destruction mechanism;

(v) Each explosive submunition is equipped with an electronic self-deactivating feature [5, article 1, p. 4].

Interestingly, the CCM does not aim at a specific failure rate; rather, while banning the vast bulk 
of current cluster munitions, it exempts those having features that it regards as likely to reduce harm to non-combatants. The CCM would dramatically reduce the number of submunitions a cluster munition contains from numbers usually in the hundreds to fewer than ten. It would also significantly increase the weight of the submunitions from less than two kilograms to more than four. Additionally, the submunitions would need to detect their target, and be electronically self-deactivating and destroying. Most current cluster munitions fail to meet any of these five requirements; the vast majority fail to meet all of them.

While the Pentagon's proposed policy and the CCM endorse specific criteria, the third condition of double-effect reasoning puts forth the ideal by which to judge both efforts; namely, the exercise of due care to eliminate or lessen harm to non-combatants. What amounts to due diligence in the avoidance of harm to non-combatants depends partially upon what currently one can practicably accomplish. Certainly, as argued, the temporal indiscriminateness exemplified by current cluster munitions falls far short of acceptable due diligence. For this reason alone, the proposed decade-long delay in the implementation of the Pentagon's policy renders it questionable vis-à-vis the above noted well established norms governing the just conduct of war.

The responsibility to insure properly functioning sub-munitions partially rests upon those who have researched and developed these weapons. Going forward, the research and development of future cluster bomb submunitions must be conducted with serious commitment to reducing dramatically and, hopefully, eliminating harm to non-combatants. The grim legacy of the flawed design of these weapons ought to serve as a cautionary tale to conscientious engineers involved in conventional-weapons' development. Perhaps cluster munitions' illustration of temporal indiscriminateness can be helpfully extended to remedy other similarly flawed 
weapons. Thus, some good might be derived from the unnecessary human anguish disproportionately born by the young - attributable to these seriously flawed weapons.

Acceptance of the status quo suggests a callous indifference to unnecessary human suffering, a violent cynicism with respect to military ethics, and a lack of imagination as to how currently available technology can better the human condition. As said of Napoleon's behavior on one occasion, "C'est plus qu'un crime, c'est une faute"; it is more than wrong, it is stupid. To develop, manufacture, or use cluster submunitions that result in such numerous avoidable civilian casualties is unjust and foolish; for both reasons it must stop.

Acknowledgements: The author expresses his gratitude for the support of a Human Rights Research Fellowship from the University of San Francisco Law School's Center for Law and Global Justice. 


\section{References}

1. Fichtelberg, A. (2006) Applying the Rules of Just War Theory to Engineers in the Arms Industry Science and Engineering Ethics 12: 685-700.

2. The Convention on Prohibitions or Restrictions on the Use of Certain Conventional Weapons Which May Be Deemed to Be Excessively Injurious or to Have Indiscriminate Effects, also known as the Convention on Certain Conventional Weapons (CCW), or Inhumane Weapons Convention. Available at: http://disarmament.un.org/ccw/.

3. Finnis, J., Boyle, J., Grisez, G. (1987), Nuclear deterrence, morality, and realism. Clarendon Press, Oxford.

4. Forge, J. (2004) The Morality of Weapons Research, Science and Engineering Ethics 10: $531-542$

5. Convention on Cluster Munitions (2008). Available at: http://treaties.un.org/doc/Publication/CTC/26_6.pdf.

6. Cicero, M. [ca. 47 b.c.] (1899) De Officiis On Duties (Book 1, Chapter 11, paragraphs 34-36) trans. Gardiner, G. (London: Methuen).

7. McGrath, R. (2000) Cluster Bombs: The Military Effect and Impact on Civilians of Cluster Munitions. Available at: www.landmineaction.org/resources/Cluster_Bombs.pdf. 8. International Committee of the Red Cross (2000) Cluster Bombs and Landmines in Kosovo: 
Explosive Remnants of War.

9. U.S. Government Accounting Office (2002) Information on U.S. Use of Land Mines in the Persian Gulf War.

10. Cavanaugh, T. (2006) Double-Effect Reasoning: Doing Good and Avoiding Evil (Oxford: Clarendon).

11. Walzer, M. (2000) Just and Unjust Wars: A Moral Argument with Historical Illustrations (3d ed.; New York: Basic Books).

12. U.S. Department of Defense Policy on Cluster Munitions and Unintended Harm to Civilians (2008). Available at: http://www.defenselink.mil/news/d20080709cmpolicy.pdf. 